\title{
Supplanting resistance of the $M i$ gene by root-knot nematode in industrial tomato in the Cerrado in Goiás State of Brazil
}

\author{
Rodrigo Vieira da Silva ${ }^{* *}$ (iD Brenda Ventura de Lima ${ }^{1}$ iD Fabricio Rodrigues Peixoto ${ }^{1}$ (iD \\ João Pedro Elias Gondim ${ }^{1}$ iD Bruno Eduardo Cardoso de Miranda $^{2}$ iD
}

${ }^{1}$ Programa de Pós-graduação em Olericultura, Laboratório de Nematologia, Instituto Federal Goiano, Campus Morrinhos, 75650-000, Morrinhos, GO, Brasil. E-mail: rodrigo.silva@ifgoiano.edu.br. "Corresponding author.

${ }^{2}$ Departamento de Fitopatologia, Instituto de Ciências Biológicas, Universidade de Brasília (UnB), Brasília, DF, Brasil.

\begin{abstract}
Problems with root-knot nematodes, caused by genus Meloidogyne, can be controlled through the introduction of resistance genes in commercial varieties of tomatoes. However, plants of the hybrid 'Heinz 9992 ' for industrial processing, carrying the Mi gene, were reported with their roots severely infected in experimental cultivation in Goiás State of Brazil with symptoms typical of galls caused by Meloidogyne spp. After dissecting the galls present in the root samples, the females of the nematodes were removed and afterwards, performed the analysis of the perineal pattern and the biochemical characterization by electrophoresis of isoenzymes, besides the pathogenicity test. The pathogen analyzed was identified as Meloidogyne incognita. The pathogenicity test confirmed the supplanting resistance of the tomato hybrid with the Mi gene by this virulent population of $M$. incognita.
\end{abstract}

Key words: Solanum lycopersicum, Meloidogyne incognita, virulence, vegetables.

Suplantação de resistência do gene $M i$ por nematoide-das-galhas em tomate industrial no Cerrado de Goiás, Brasil

RESUMO: Problemas causados pelos nematoides-das-galhas, pertencentes ao gênero Meloidogyne podem ser controlados com a introdução de genes de resistência em cultivares comerciais de tomateiro. No entanto, plantas do híbrido 'Heinz 9992 ' adequadas ao processamento industrial, portadoras do gene Mi, foram encontradas com suas raizes severamente infectadas, em um cultivo experimental no municipio de Morrinhos (GO) com sintomas tipicos de galhas causadas por Meloidogyne spp. Após dissecar as galhas presentes nas amostras de raizes, as fêmeas do nematoide foram retiradas para a análise do padrão perineal e a caracterização bioquímica por eletroforese de isoenzimas, além do teste de patogenicidade. O patógeno em estudo foi identificado como Meloidogyne incognita. O teste de patogenicidade confirmou que ocorreu a suplantação de resistência do hibrido de tomateiro, portador do gene Mi, por esta população virulenta de M. incognita.

Palavras-chave: Solanum lycopersicum, Meloidogyne incognita, virulência, hortaliças.

Brazil is one of the main industrial tomato producing countries, accounting for $5 \%$ of world production (WPTC, 2018), and the state of Goiás is responsible for the largest production in the country, about $80 \%$.

The root-knot nematodes, caused by genus Meloidogyne, is among the main phytosanitary problems of industrial tomatoes, frequently reported as host of the main species of root-knot nematodes present in Brazil, which can cause up to $85 \%$ losses in productivity (FERRAZ \& CHURATA-MASCA, 1983).

Among the control methods, the most economical and recommended is the use of resistant cultivars that considerably reduce crop damage. The presence of the $M i$ gene confers resistance to $M$. incognita, M. javanica, M. arenaria and to insects such as aphids and whiteflies.

Some species and/or populations of Meloidogyne called virulent pathotypes have the capacity to withstand high temperatures and supplant the resistance conferred by the $M i$ gene (CORTADA et al., 2011). In addition, expression of the $M i$ gene is heat sensitive and its effect can be lost when the soil temperature surpasses $28^{\circ} \mathrm{C}$, allowing the nematode to reproduce in the plant root, even if it contains the resistance gene (DROPKIN, 1969).

Therefore, the objective of this research was to study the possible supplanting of resistance to the Mi gene by M. incognita in the 'Heinz 9992' industrial tomato, in the Cerrado in Goiás State of Brazil. 
In April 2016, in the city of Morrinhos in the south of the state of Goiás, plants of the tomato hybrid 'Heinz 9992', carrying the $M i$ gene, were reported to be severely infected by the knot-root nematode in the experimental planting of industrial tomatoes with drip irrigation. Samples of roots infected with nematodes were collected and taken to the laboratory for being analyzed under the stereoscopic equipment, females with typical characteristics of the genus Meloidogyne were removed (Figure 1B). The perineal configuration was observed in 20 females, as well as the biochemical analysis of the enzymes esterase (EST) and malate-dehydrogenase (MDH) profiles by the vertical discontinuous electrophoresis technique (FREITAS et al., 2016).
The study of pathogenicity was performed in a greenhouse, during the experimental period the minimum and maximum air temperatures were 19.3 and $26.5{ }^{\circ} \mathrm{C}$, respectively. Reproduction of the $M$. incognita population in resistant cultivar Motelle carrying the $M i$ gene and the Santa Cruz 'kada' susceptibility standard was evaluated. Nematode eggs and second-stage juveniles (Figure 1A) were extracted according to the method of HUSSEY \& BARKER (1973) modified by BONETI \& FERRAZ (1981). The experiment was installed in a completely randomized design with six replicates. At 60 days after inoculation the number of galls and eggs by root system were evaluated. The gall index was assigned for TAYLOR \& SASSER (1978). The reproduction

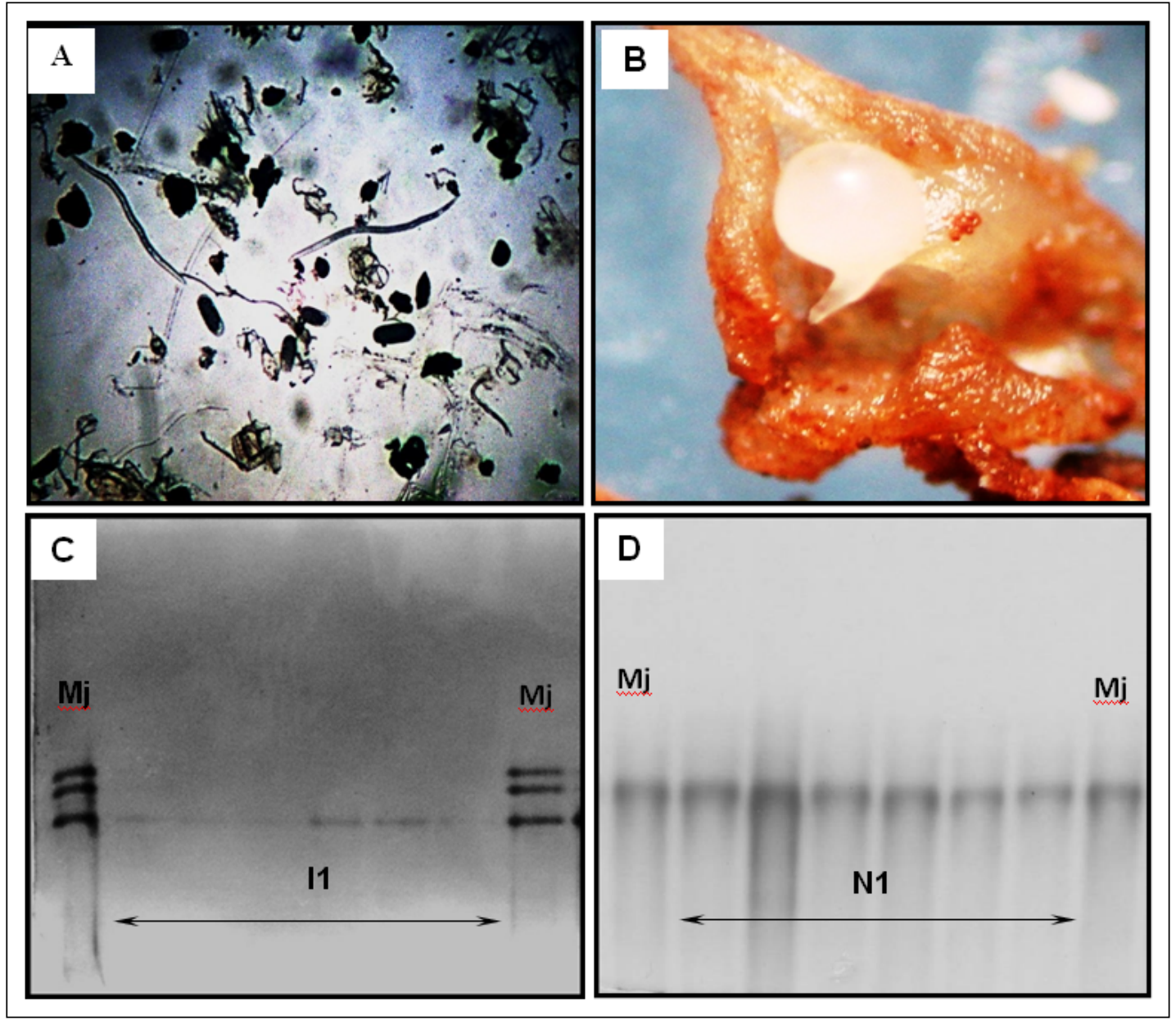

Figure 1 - Root-knot nematode, Meloidogyne incognita, extracted of roots of plants of the tomato hybrid 'Heinz 9992', which contains the $M i$ gene. A: Eggs, second-stage juveniles. B: Female adult exposed outside the root. Isozymatic phenotypes. C: phenotype I1 - of esterase; D: phenotype N1 - of malate dehydrogenase. Mj: phenotype of M. javanica used as the standard of comparison. Designation of phenotypes: EST $=$ esterase and $\mathrm{MDH}=$ malate dehydrogenase. 
factor $(\mathrm{FR}=$ final nematode population/initial nematode population) was calculated according to OOSTENBRINK (1966). The means of the treatments were compared by the Tukey test, at 5\% probability. Statistical analysis was performed using the software Sisvar ${ }^{\circledR}$ software (FERREIRA, 2011).

In the perineal region, the patterns of the dorsal, trapezoidal and smooth arches were evaluated and we reported corrugated striations and some nearby bifurcations. These characteristics are more common in the species $M$. incognita and $M$. paranaensis, inducing the identification error; and although, this description refers to the typical pattern, some configurations with lower dorsal arch were also observed. Isoenzymatic of esterase (EST-I1) and malate dehydrogenase (MDH-N1) phenotypes showed patterns characteristic of $M$. incognita specie (Figure 1C-D). However, for more refined phylogenetic studies a more complete diagnosis using molecular techniques is also suggested (CUNHA, et al., 2018).

According to the pathogenicity test the mean number of galls, eggs and RF were higher $(p \leq 0.05)$ in the cultivar Santa Cruz 'Kada'; however, the cultivar Motelle, which carries the gene $M i$, also allowed reproduction of the $M$. incognita population (Table 1).

The supplanting of resistance in 'Heinz 9992' tomato plants by M. incognita may be related to the intraspecific variation of the local population of this nematode, soil temperature or exhaust of the hybrid, which may have segregated the resistance gene. At the same site, another tomato hybrid with the $M i$ gene, also intended for industrial processing, 'BRS Sena', was cultivated and showed no symptoms of infection.
The variability in the virulence of the genus Meloidogyne, including M. incognita, has been reported in the literature even in apomictic species that reproduce by mitotic parthenogenesis, mainly in Europe (CASTAGNONE-SERENO, 2002). Individuals or populations of Meloidogyne spp. naturally virulent to the $M i$ gene may occur even without selection pressure and is not rare; several cases have already been reported in European countries (CORTADA et al., 2011). One of the hypotheses raised is that this phenomenon is caused by the selection pressure by the repeated exposure of the cultivar ported from the $M i$ gene to the nematode, either in the field or laboratory. However, in the area where the $M$. incognita population was collected it is not an area of tomato production, this being the first year of cultivation, so that this is a native virulent population. The gene mutation is probably the main mechanisms of variability in Meloidogyne species that reproduces by mitotic parthenogenesis (CARNEIRO et al., 2017). However, in Brazil, despite the use of resistant tomato cultivars for several decades, there is still no report of a breakdown in resistance to the Mi gene.

The phytonematode, M. incognita, has the capacity to overcome the resistance conferred by the $M i$ genes, making it indispensable to the continuous search of new sources of resistance to populations of Meloidogyne that infect the tomato destined for agroindustry.

Confirming the Supplanting resistance of the $M i$ gene by population root-knot nematode in industrial tomato. This is the first record of resistance uptake in tomato with $\mathrm{Mi}$ gene in Brazil.

Table 1 - Number of galls (NG) and number of eggs (NE), reproduction factor (RF), gall index (GI) and host status per root system of tomato from cultivars Santa Cruz 'Kada' (susceptible) and Motelle (resistant) inoculated with 5,000 eggs per plant of the virulent population of Meloidogyne incognita at 60 days after inoculation.

\begin{tabular}{lccccc}
\hline Cultivars & ${ }^{2} \mathrm{NG}$ & GI & ${ }^{2} \mathrm{NE}$ & ${ }^{3} \mathrm{RF}$ & Host status \\
\hline Motelle (With $\mathrm{Mi})$ & $157 \mathrm{a}$ & 5 & $14.693 \mathrm{a}$ & 2,94 & $\mathrm{~S}$ \\
Santa Cruz 'Kada' & $324 \mathrm{~b}$ & 5 & $33.748 \mathrm{~b}$ & 6,74 & $\mathrm{~S}$ \\
\hline Coefficient of variation (\%) & 19,64 & & 22,35 & & \\
\hline
\end{tabular}

For NG and NE, the means followed by the same letter are not significantly different $(P=0.05)$. GI $=$ Gall Index $(0-5)$ : $0=$ no galls, $1=$ $1-2,2=3-10,3=11-30,4=31-100,5=>100$ galls per root system) assigned for Taylor \& Sasser (1978). RF (reproductive factor) $=$ Pf/initial nematode population density (OOSTENBRINK, 1966). 4) Host status categories: R = resistant $(\mathrm{RF} 1$ and GI 2); RH = resistant $(\mathrm{RF} 1$ and $\mathrm{GI}>2)$; $\mathrm{S}=$ susceptible $(\mathrm{RF}>1$ and $\mathrm{GI}>2)$. 


\section{ACKNOWLEDGEMENTS}

The authors thank the following Brazilian Institutes for financial support: Fundação de Amparo a Pesquisa do Estado de Goiás (FAPEG), Coordenação de Aperfeiçoamento de Pessoal de Nível Superior (CAPES), Conselho Nacional de Desenvolvimento Científico e Tecnológico (CNPq) and Instituto Federal Goiano. The authors would like to express their appreciation to $\operatorname{Prof}^{\mathrm{a}} \mathrm{Dr}^{\mathrm{O}}$ Dalila Sêni Buonicontro from the Laboratory of Nematology of the Federal University of Viçosa from support in identifying the nematode species.

\section{DECLARATION OF CONFLICT OF INTERESTS}

The authors declare no conflict of interest. The founding sponsors had no role in the design of the study; in the collection, analyses, or interpretation of data; in the writing of the manuscript, and in the decision to publish the results.

\section{AUTHORS' CONTRIBUTIONS}

All authors contributed equally for the conception and writing of the manuscript. All authors critically revised the manuscript and approved of the final version.

\section{REFERENCES}

BONETI, J. I. S.; FERRAZ, S. Modificação do método de Hussey \& Barker para extração de ovos de Meloidogyne exigua de raízes de cafeeiro. Fitopatologia Brasileira, v.6, p.553, 1981. Available from: $<$ https://www.scienceopen.com/document?vid=9232a12b2a57-4b2b-8724-dae6ad63e065>. Accessed: Feb. 05, 2018.

CARNEIRO, M. S. et al. Lack of association between $\boldsymbol{r r l}$ and $\boldsymbol{e r m}$ (41) mutations and clarithromycin resistance in Mycobacterium abscessus complex. Memórias do Instituto Oswaldo Cruz, v.112, p.775-778, 2017. Available from: <http://www.scielo.br/scielo. php script $=$ sci arttext\&pid $=$ S00742762017001100775\&lang $=$ pt>. Accessed: May, 15, 2018. doi: 10.1590/0074-02760170080.

CORTADA, L. et al. Meloidogyne virulence locus molecular marker for characterization of selected $\mathrm{Mi}$-virulent populations of Meloidogyne spp. is correlated with several genera of Betaproteobacteria. Phytopathology, v.101, p.410-415, 2011. Available from: <https://apsjournals.apsnet.org/doi/pdf/10.1094/ PHYTO-04-10-0123>. Accessed: Nov. 12, 2017. doi: 10.1094/ PHYTO-04-10-0123.
,CUNHA, T. G. et al. Diagnostic methods for identification of root-knot nematodes species from Brazil. Ciência Rural, v.48, e20170449. 2018. Available from: <http://www. scielo.br/scielo.php?pid=S010384782018000200153\&scr ipt $=$ sci_abstract\&tlng=en $>$. Accessed: Dec. 18, 2018. doi: $10.1590 / 0103-478 \mathrm{cr} 20170449$.

DROPKIN, V. H. The necrotic reaction of tomatoes and other hosts resistant to Meloidogyne: reversal by temperature. Phytopathology, v.59, p.1632-1637, 1969. Available from: $<$ https://eurekamag.com/research/014/757/014757499.php >. Accessed: Nov. 12, 2017.

FERRAZ, L. C. C. B.; CHURATA-MASCA, M. G. C. Comportamento de cultivares de tomateiro (Lycopersicon esculentum, Mill) de crescimento determinado em relação ao nematoide Meloidogyne incognita (Kofoid \& White, 1919) Chitwood. Científica, v.11, p.87-91, 1983. Available from: <https://www.researchgate.net/ publication/286040055_Comportamento_de_cultivares_de_ tomateiro_Lycopersicon_esculentum_Mili_de_crescimento_determinado_em relacao ao nematoide Meloidogyne incognita_Kofoid_White_1919_Chitwood_1949>.Accessed: May, 20, 2018.

FERREIRA, D. F. Sisvar: a computer statistical analysis system. Ciência e Agrotecnologia, v.35, p.1039-1042, 2011. Available from: $<$ http://www.scielo.br/scielo.php?script=sci_arttext\&pid=S 14130542011000600001\&lang=pt $>$. Accessed: Apr. 23, 2018. doi: 10.1590/s1413-70542011000600001.

FREITAS, L. G. et al. Métodos em nematologia vegetal. In: ALFENAS, A.C.; MAFIA, R.G. Métodos em Fitopatologia. Viçosa: Universidade Federal de Viçosa, 2016. $2^{\circ}$ Ed. Cap.11, p.275-284.

HUSSEY R. S.; BARKER K. R. 1973. A comparison of methods colleting inocula of Meloidogyne spp. including a new technique. Plant Disease Reporter, v.57, p.1025-1028, 1973.

OOSTENBRINK, M. Major characteristics of the relation between nematodes and plants. Wageningen: Landbouwhogeschool Wageningen, 1966. 46p.

TAYLOR, A. L.; SASSER, J. N. Biology, identification and control of root-knot nematodes (Meloidogyne species). Raleigh: North Carolina State University, 1978. 111p.

WORD PROCESSING TOMATO COUNCIL - WPTC. Banco de dados. Monteux: WPTC. Available from: <www.eptc.to>. Accessed: Aug. 10, 2018. 